\title{
PRECISION CANOPY MANAGEMENT OF THE GRAPEVINE: EARLY DEFOLIATION AND GIRDLING
}

\author{
Adrienn Mária Tóth ${ }^{1}$ \\ ${ }^{1}$ Institute of Viticulture and Enology, Eszterházy Károly University, Eger.
}

\begin{abstract}
Although different operations are applied in the cultivation of both wine grape and table grape varieties, the purpose is to produce healthy crop having the desired quality values, with the least possible amount of pesticide applied. Environmental risks and climate change are also becoming increasingly important issues in sustainable agricultural management. Early defoliation and girdling as precision phytotechnical methods can be used to implement the requirements of environmental consciousness and to achieve adequate grape quality parameters in wine making and table grape growing. Early defoliation of the cluster zone increases berry quality and reduces the possibility of rot infection by changing the microclimatic environment around the cluster and improving berry skin resistivity (Poni et al. 2006; Pastore et al. 2013).
\end{abstract}




\section{Introduction}

Apparently, attaining optimal quality parameters of juice and physical quality of berry is the aim of both wine and table grape growing. In practice this means that we want to influence such parameters of wine grapes that will be decisive in the winemaking process, such as sugar content, anthocyanin and phenolic concentration. On the other hand, in the case of table grapes, marketability is the main factor, which is highly influenced by consumer demand. Therefore, the market value of table grapes is mainly influenced by berry size, firmness, color and taste. The desired parameters of both grape types are determined primarily by the variety of the grape, the terroir and the climate and, not least, by the viticulture practices, use of plant chemicals and the agro- and phytotechnical operations applied (Gabura, 2018). The practice of using precision phytotechnical operations has an increasing importance in conscious quality grape-growing worldwide, although they are less known in Hungary and related scientific studies are quite sparse.

Due to the nature of the vine, one of the most important viticultural tasks is to establish vine balance in order to adjust the optimum yield with the adequate. This is a multi-step, labor intensive process that lasts from winter pruning to the harvest of the bunches. Following the appearance of the shoots, canopy management can contribute to obtaining the desired fruit quantity and quality by adjusting the proportion of vegetative and generative organs. These parameters depend on the optimal carbohydrate balance of the leaves and shoots from growing to ripening (Mota et al. 2009, Frioni et al. 2017). A significant number of phytotechnical treatments are generally applied to maintain the optimal proportion of vegetative and generative plant parts (e.g. pruning, shoot thinning) (Bényei et al. 1999). Other lesser known types of phytotechnical treatments include the special or precision procedures that can improve the quality parameters of the grape by modifying the formation and further development of the flowers and fruit clusters through affecting the reproductive activities of the plant (Bényei et al. 1999).

A plant organ can be either source or sink during assimilate partitioning. In simple terms about the relations of the assimilate transport between the sink and source organs are effected by the ratio of leaf to yield ratio (sink-source relations) (Conde et al. 2007). For example, the ratio of the leaf area as assimilate source will become greater by cluster thinning than the bunches. Therefore, excessive crop load can be prevented and enhanced grape quality can be achieved (Mota et al. 2009). Some methods such as cluster thinning or girdling operate by changing the distribution ratio of the assimilates produced by the photosynthesis can enhance maturation and thus their use is quite essential in cool-climate regions (Frioni et al. 2017)

These special canopy management methods can rarely be mechanized and, due to the time consuming nature of manual labor, are only applied in wine grape cultivation 
in special cases and for specific production purposes, while some of them can be essential in the case of table grapes (Lörincz-Barócsi, 2010). These viticulture practices can be manual/mechanical, meaning that certain parts of the plant are removed for a positive result, or chemical, when phytotechnical hormones are used to stimulate the growth and maturation of the bunches (Lörincz-Barócsi, 2010). The latter method is common practice with seedless grape varieties. Exogenous application of gibberellic acid during flowering reduces the berry set and a repeated application of the hormone increases the berry size during the development (Roper-Williams, 1989).

The role of special canopy management techniques is increasing under extreme environmental conditions due to climate change. It is well known, that water deficit and high air temperature increase phenolic grape maturity, however sugar concentration become also high in the berries (Cohen et al., 2008, 2012; De Orduna et al. 2010; Villangó et al. 2016). Therefore, the optimal use of different viticultural techniques (including canopy management) may help to balance fruit maturity (Poni et al, 2006; Palliotti et al. 2014).

\section{Special phytotechnical practices in cool climate regions}

Table grape growing is quite difficult in Hungary - as compared to the Mediterranean countries - because of the cool climate conditions. The annual precipitation and humidity distribution is irregular, the weather during the growing period (from May to October) is warm, but sometimes at the beginning of October the early frosts can stop the ripening process in the case of late maturity varieties (eg. Italia, Afuz Ali). Humidity in late August and September causes several fungal diseases in grapes, and chemical defense not always possible because of the withdrawal period of chemical products used in food production. Some special phytotechnical operations such as defoliating and girdling can be applied as an environmentally friendly method for improving grape quality.

\section{Early defoliation}

Early defoliating of the cluster zone increases berry quality and reduces the possibility of rot infection by changing the microclimatic environment around the cluster and by improving berry skin resistivity (Poni et al. 2006; Pastore et al. 2013); however, this method is not commonly used in Hungary. Implementation of this method involves removal of leaves in the cluster zone or defoliating basal leaves, which can produce different results based on the timing of the treatment. Early defoliation (timing before 
anthesis or berry set) by removing the basal leaves reduces the carbohydrate supply of the bunches and thereby results in insufficient berry set. The clusters will be less dense, with a smaller number of berries, compared to the control vines (Poni et al. 2006; Diago et al. 2010; Sabbatini-Howell, 2010). In order to achieve such positive effects as yield reduction, loose clusters and higher sugar concentration, defoliation should be applied at least four weeks after blooming (Sabbatini-Howell, 2010)

Changes in yield and cluster structure have been confirmed by several studies (Diago et al. 2010; Tardaguila et al. 2010; Fazekas, 2012; Gabura, 2018). The decline in yields caused by early defoliation is primarily due to lower cluster weight (Pastore et al, 2013). According to a study made in two consecutive year both mechanical and manual pre-bloom defoliation resulted in lower yields, smaller bunches and less berries per cluster compared to the control, whereas only mechanical defoliation produced results when applied at anthesis (Diagoe et al. 2010), and total leaf area was similar to that in the controls as a result of post-leaf regeneration, and greater resistance to botrytis infections was observed (Diagoe et al. 2010).

Comparison of the results of several studies shows that early defoliation does not produce an equable change in the berry weight of different varieties. Tardaguila et al. (2010) found a decrease berry weight on Graciano variety, while the weight of the berries increased as a result of the early defoliation on Carignan variety. Berry weight decreased in the case of defoliated Kékfrankos, while it increased as a result of the treatment in the Turán variety (Fazekas, 2012). However, other studies reported that the experiment did not effect any changes in the berry weight of Pinot noir (LeeSkinkis, 2013) or Tempranillo (Diago et al. 2010).

Besides yield decrease, positive changes occur in juice quality as a result of the treatment. The sugar content increased and the titratable acidity declined in the examined varieties as the result of early defoliation (Poni et al. 2006; Pastore et al. 2013, Gabura, 2018). According to studies, the decrease of acidity can often be cultivar-specific, as in the case of the Vignoles variety (Sabbatini-Howell, 2010), or in Kékfrankos and Turán there were no significant changes (Fazekas, 2012).

Increased light exposure and better leaf area fruit weight ratio may also affect the polyphenol and anthocyanin content of grapes. Higher light intensity produces more phenolic compounds in the plant through enhancing the enzymatic activity (Zanathy, 2003). Wines will be deeper in color and longer in taste, owing to the defoliation (Lőrincz-Barócsi, 2010). Several studies reported that defoliation increased the amount of phenolic compounds. Total polyphenol and anthocyanin content increased on Graciano variety due to early defoliation in two consecutive years (Tardaguila et al. 2010), and both compounds increased significantly on Turán variety (Fazekas 2012) and also on the Tempranillo variety (Diago et al. 2012) as a result of the treatment. Intrigliolo et al. (2014) came to similar conclusions concerning the Mandó grape variety (Gabura, 2018). 
The timing of leaf removal is also decisive in achieving the expected results. Lee and Skinkis's (2013) experiment revealed that the anthocyanin content of the grape crop increased the most if the defoliation was applied during flowering, compared to the control and vines which that defoliated in another phenological phase (e.g. grainpea size or bunch closure) (Gabura, 2018). Application of leaf removal from prebloom vines increased the anthocyanin content, compared with the control (Poni et al. 2006), while treatment at veraison resulted in a reduced amount of anthocyanin on Sangiovese variety (Pastore et al. 2013).

A general inconvenience in cool climate vine growing is that the dry and warm growing season, which provides optimal ripening conditions, is relatively short and the increased precipitation in autumn often results in the rotting of mature or ripening bunches. The frequency and extent of gray rot depends greatly on the microclimate of the cluster zone, temperature, wind velocity, humidity and leaf moisture (LőrinczBarócsi, 2010, Gabura, 2018). Early defoliation contributes positively to both the environmental and internal factors, thus reducing the incidence of botrytis infection. This can be explained by a looser cluster structure due to a poor berry set and, on the other hand, by the thickening of the cuticule layer of the berries that initially developed under greater light exposure (Zanathy, 2003; Lőrincz-Barócsi, 2010; Gabura, 2018). These beneficial effects were showed by Diagoe et al. (2012) when high levels of rainfall caused serious infections in control vines, but the early defoliation reduced the botrytis infection in the Tempranillo variety significantly. The degree of infection is also reduced by defoliating at veraison (Pastore et al. 2017).

\section{Girdling at veraison}

Girdling means removing a small section of bark $(3-6 \mathrm{~mm})$ from the trunk, a bunch or shoot of a woody plant. Usually it is done with a special girdling tool which does not harm the cork of the plant. The wound on the phloem behaves as a physical barrier in the way of assimilates and hormones from leaves to roots, consequently inducing their accumulation; while water and minerals can be transported from roots to leaves without any obstacle. The carbohydrate supply, auxin and ABA quantity increases, and the cytokinine level decreases above the girdled wound.

Different timings of girdling resulted in different positive effects on berries; during anthesis it improves berry set, especially in seedless cultivars; after berry set it improves berry size (Dokoozlian et al. 1995; Brar et al. 2008; Soltekin et al. 2015, 2016). Effects of accelerated maturity and enhanced, balanced colouring of the grape berries can be achieved by girdling at veraison. Girdling causes earlier harvest dates (Keskin et al. 2013; Soltekin et al. 2015 and 2016; Basile et al. 2018) by 6-15 days 
(Soltekin et al. 2016) and this can be favourable in cool climate vineyards. Girdling executed at the beginning of veraison on table grapes can accelerate the colouring of the berries (Yamane-Shibayama, 2006; Yamane et al. 2010; Koshita et al. 2011). The finding that girdling caused enhanced maturity in grapes was supported in several studies by lower acidity and higher sugar content values of the treated berries (Yamane and Shibayama, 2006; Keskin et al. 2013; Soltekin et al. 2015 and 2016).

Girdling at veraison may cause accumulation of several components in plants above the ringing of the phloem including clusters, and thus it results in improved maturity (Roper-Williams, 1989; Yamane-Shibayama, 2006; Koshita et al. 2011; Abu-Zahra and Salameh, 2012; Keskin et al. 2013; Ferrara et al. 2014; Soltekin et al. 2015.) The impact of girdling is commonly evaluated by berry or cluster size parameters and changes in total soluble solids (Zabadal, 1992; Abu-Zahra - Salameh, 2012, Ferrara et al. 2014; Soltekin et al 2015, 2016) or increasing Brix values and total extractable polyphenols (Basile et al, 2018). Relatively few studies investigate the effect of girdling on wine grapes. Peduncle girdling in the Shiraz wine grape variety in warm climate did not significantly alter the volatile compounds of the wine (Böttcher et al. 2018).

Girdling causes assimilate accumulation above the ring wound with higher leaf water potential due to stomatal closure. Presumably the ABA concentration induced a decreased stomatal activity (Düring, 1978), similarly to the effect of water deficit (Zsófi et al. 2008). Similar results were found by Ezzahouani and Williams (2001) and a reduced net $\mathrm{CO} 2$ assimilation rate was observed above the girdling (Roper and Williams, 1989).

Girdling can be an effective complement to other methods. Combined use with cluster thinning is an effective agronomical technique to enhance berry quality (Basile et al. 2018) and it can also increase the berry weight (Zabadal, 1992). Application of the method during anthesis or berry set with exogenous growth hormones is common in the case of seedless cultivars, because the gibberellin production of the plant is not sufficient to achieve berry size. (Zabadal, 1992; Williams-Ayars, 2005, Zhang et al. 2003; Reynolds-Savigny, 2004; Abu-Zahra, 2010, Abu-Zahra - Salameh, 2012).

\section{Conclusion}

In summary, early leaf removal has positive effects on crop quality by limiting yield and increasing phenolic compounds, while looser cluster structure and thicker cuticule layer formation as a result of defoliation reduces the risk of botrytis infection. This method is adequate for producing high quality red wines with increased anthocyanin and phenolic compounds. Girdling applied at veraison can be effective in cool climate 
table grape growing, as the method accelerates the ripening process and increases the nutritional values of the grape. However, research on the effect of girdling is still sporadic in the case of wine grapes.

\section{Acknowledgement}

This work is supported by EFOP-3.6.2-16-2017-00001.

\section{References}

[1.] Abu-Zahra, T. R. (2010). Berry size of Thompson Seedless as influenced by the application of gibberellic acid and cane girdling. Pakistan Journal of Botany, 42 (3), 1755-1760.

[2.] Abu-Zahra, T. R., Salameh, N. M. (2012). Influence of Gibberellic Acid and Cane Girdling on Berry Size of Black Magic grape cultivar. Middle-East Journal of Scientific Research, 11 (6), 718-722.

[3.] Basile, T., Alba, V., Gentilesco, G., Savino, M., Tarricon, L. (2018). Anthocyanins pattern variation in relation to thinning and girdling in commercial Sugrathirteen table grape. Scientia Hortuculturae, 227, 202-206 https://doi.org/10.1016/j.scienta.2017.09.045

[4.] Bényei, F., Lőrincz, A., Nagy, Sz. L., (1999). Szőlőtermesztés. Mezőgazda Kiadó, Budapest.

[5.] Böttcher, C.; Boss, P. K.; Harvey, C.A.; Davies, C. (2018). Peduncle-girdling of Shiraz (Vitis vinifera L.) bunches and sugar concentration at the time of girdling affect wine volatile compounds. Australian Journal of Grape and Wine Research 24 (2), 206-218.

https://doi.org/10.1111/ajgw.12319

[6.] Brar, H. S., Singh, Z., Swinny, E., Cameron, I. (2008). Girdling and grapevine leafroll associated viruses affect berry weight, colour development and accumulation of anthocyanins in 'Crimson Seedless' grapes during maturation and ripening. Plant Science, 175, 885-897.

https://doi.org/10.1016/j.plantsci.2008.09.005 
[7.] Cohen, S. D., Tarara, J. M., \& Kennedy, J. A. (2008) Assessing the impact of temperature on grape phenolic metabolism. Analytica Chimica Acta, 621(1), 57-67.

https://doi.org/10.1016/j.aca.2007.11.029

[8.] Cohen, S. D., Tarara, J. M., Gambetta, G. A., Matthews, M. A., \& Kennedy, J. A. (2012) Impact of diurnal temperature variation on grape berry development, proanthocyanidin accumulation, and the expression of flavonoid pathway genes. Journal of Experimental Botany, 63(7), 2655-2665.

https://doi.org/10.1093/jxb/err449

[9.] Conde, C., Silva, P; Fontes, N., Dias, A. C. P., Tavares, R. M., Sousa, M. J., Agasse, A., Delrot, S., Gerós, H. (2007): Biochemical Changes throughout Grape Berry Development and Fruit and Wine Quality. Food. Global Science Books: 1-22.

[10.] De Orduna, R. M. (2010) Climate change associated effects on grape and wine quality and production. Food Research International, 43(7), 1844-1855. https://doi.org/10.1016/j.foodres.2010.05.001

[11.] Diago P. M., Vilanova M., Tardaguila J. (2010): Effects of Timing of Manual and Mechanical Early Defolation on the Aroma of Vitis vinifera L. Tempranillo Wine. American Journal of Enology and Viticulture 61 (3), 382-391.

[12.] Diago, P. M.; Ayestarán, B; Guadalupe, Z., Poni, S., Tardaguila, J. (2012). Impact of prebloom and fruit set basal leaf removal on the flavonol and anthocyanin composition of Tempranillo grapes. American Journal of Enology and Viticulture 63 (3), 367-376.

https://doi.org/10.5344/ajev.2012.11116

[13.] Dokoozlian, N., Luvisi, D., Moriyama, M., Schrader, P. (1995). Cultural practices improve colour, size of 'Crimson Seedless'. California Agriculture, 49 (2), 36-40.

https://doi.org/10.3733/ca.v049n02p36

[14.] Düring, H. (1978). Untersuchungen zut Umweltabhängigkeit der stomatären Transpiration bei Reben. II: Ringelungs- und Temperatureffekte. Vitis, 17, $1-9$.

[15.] Ezzahouani, A., Williams, L. E. (2001). The effects of thinning and girdling on leaf water potential, growth and fruit composition of Ruby seedless grapevines. J. Int. Sci. Vigne Vin, 35 (2), 79-85. https://doi.org/10.20870/oeno-one.2001.35.2.985 
[16.] Fazekas, I. (2012): Terméskorlátozó fitotechnikai munkák hatása vörösborszőlőfajtákra. Budapest. Doktori értekezés.

[17.] Ferrara, G., Mazzei, A., Netti, G., Pacucci, C., Mataresse, A. M. S., Cafagna, I., Mastrorilli, P., Vezzoso, M., Gallo, V. (2014): Girdling, Gibberelic Acid and Forchlorfenuron: Effects on Yield, Quality, and Metabolic Profile of Table Grape cv. Italia. American Journal of Enology and Viticulture, 65 (3), 381-387. https://doi.org/10.5344/ajev.2014.13139

[18.] Frioni, T., Zhuang, S., Palliotti, A., Sivilotti, P., Falchi, R., Sabbatini, P. (2017): Leaf removal and cluster thinning efficiencies are highly modulated by environmental conditions in cool climate viticulture. American Journal of Enology and Viticulture 68:4, 325-335.

https://doi.org/10.5344/ajev.2017.16098

[19.] Gabura, P. (2018): Különböző terhelés és lelevelezés hatása, a Furmint fajta mennyiségi és minőségi paramétereire. Szakdolgozat. Eszterházy Károly Egyetem.

[20.] Intrigliolo, S. D., Llacer, E., Revert, J., Esteve, D. M., Climent, D. M., Palau, D., Gómez, I. (2014): Early defoliation reduces cluster compactness and improves grape composition in Mandó, an autochthonous cultivar of Vitis vinifera from southeastern Spain. Scientia Horticulturae, 167, 71-75. https://doi.org/10.1016/j.scienta.2013.12.036

[21.] Keskin, N., İş̧̧i, B., Gökbayrak, Z. (2013). Effects of cane-girdling and cluster and berry thinning on berry organic acids of four Vitis vinifera L. table grape cultivars. Acta Scientiarium Polonorum, 12 (6), 115-125.

[22.] Koshita, Y., Yamane, T., Yakushiji, H., Azuma, A., Mitani, N. (2011). Regulation of skin colour in 'Aki Queen' grapes: Interactive effects of temperature, girdling, and leaf shading treatments on coloration and total soluble solids. Scientia Horticulturae, 129, 98-101.

https://doi.org/10.1016/j.scienta.2011.03.014

[23.] Lee, J., Skinkis, A. P. (2013): Oregon 'Pinot noir' grape anthocyanin enhancement by early leaf removal. Food Chemistry 139, 893-901. https://doi.org/10.1016/j.foodchem.2013.02.022

[24.] Lőrincz, A., Barócsi, Z. (szerk.) (2010). A szőlő metszése és zöldmunkái. Mezőgazda Kiadó, Budapest. 
[25.] Mota, R. V., Souza, C. R., Silva, C. P., Freitas, G. F., Shiga, T. M., Purgatto, E., Lajolo, F. M., Regina, M. A. (2009): Biochemical and agronomical responses of grapevines to alteration of source-sink ratio by cluster thinning and shoot trimming. Bragantia 69 (1): 17-25. https://doi.org/10.1590/S0006-87052010000100004

[26.] Palliotti, A., Tombesi, S., Silvestroni, O., Lanari, V., Gatti, M., \& Poni, S. (2014). Changes in vineyard establishment and canopy management urged by earlier climate-related grape ripening: A review. Scientia Horticulturae, 178, 43-54.

https://doi.org/10.1016/j.scienta.2014.07.039

[27.] Pastore, C., Allegro, G., Valentini, G., Muzzi, E., Filippetti, I. (2017): Anthocyanin and flavonol composition response to veraison leaf removal on Cabernet Sauvignon, Nero d'Avola, Raboso Piave and Sangiovese Vitis vinifera L. cultivars. Scientia Horticulturae 218, 147-155. https://doi.org/10.1016/j.scienta.2017.01.048

[28.] Pastore, C., Zenoni, S.,Fasoli, M., Pezzotti, M., Tornielli, B. G., Filippetti I (2013): Selective defolation affects plant growth, fruit transcriptional ripening program and flavonoid metabolism in grapevine. BMC Plant Biology, 13:30. https://doi.org/10.1186/1471-2229-13-30

[29.] Poni, S., Casalini, L., Bernizzoni, F., Civardi, S., Intrieri, C. (2006): Effects of Early Defoliation on Shoot Photosynthesis, Yield Components and Grape Composition American Journal of Enology and Viticulture 57(4),397-407.

[30.] Reynolds, A. G., Savigny, C. de. (2004). Influence of girdling and gibberellic acid on yield components, fruit composition and vestigial seed formation of 'Sovereign Coronation' table grapes. Hort. Science, 39 (3), 541-544. https://doi.org/10.21273/HORTSCI.39.3.541

[31.] Roper, T. R., Williams, L. E. (1989): Net CO2 Assimilation and Carbohydrate Partitioning of Grapewine Leaves in Response to Trunk Girdling and Gibberellic Acid Application. Plant Physiology 89: 1136-1140. https://doi.org/10.1104/pp.89.4.1136

[32.] Sabbatini, P., Howell, G. S. (2010): Effects of early defoliation on yield, fruit composition, and harvest season cluster rot complex of grapevines. Hort. Science 45 (12), 1804-1808. https://doi.org/10.21273/HORTSCI.45.12.1804 
[33.] Soltekin, O., Candemir, A., Altindisli, A. (2016): Effects of cane girdling on yield, fruit quality and maturation of (Vitis vinifera L.) cv. Flame Seedless. BIO Web of Conferences 7 (01032): 1-5.

https://doi.org/10.1051/bioconf/20160701032

[34.] Soltekin, O., Teker, T., Erdem, A., Kacar, E., Altindisli, A. (2015): Response of "Red Globe" (Vitis vinifera L.) to cane girdling. BIO Web of Conferences 5: (01019)

https://doi.org/10.1051/bioconf/20150501019

[35.] Tardaguila, J., Toda, F. M., Poni, S., Diago, M. P. (2010): Impact of Early Leaf Removal on Yield and Fruit and Wine Composition of Vitis vinifera L. Graciano and Carignan. American Journal of Enology and Viticulture, 61, 372381.

[36.] Villangó, S., Szekeres, A., Bencsik, O., Láposi, R., Pálfi, Z., \& Zsófi, Z. (2016). The effect of postveraison water deficit on the phenolic composition and concentration of the Kékfrankos (Vitis vinifera L.) berry. Scientia Horticulturae, 209, 113-116.

https://doi.org/10.1016/j.scienta.2016.06.010

[37.] Williams, L. E., Ayars, J. E. (2005). Water use of Thompson Seedless grapevines as affected by the application of gibberelic acid (GA3) and trunk girdling - practices to increase berry size. Agricultural and Forest Meteorology, 129 (1-2), 85-94.

https://doi.org/10.1016/j.agrformet.2004.11.007

[38.] Yamane, T., Miyake, S., Hamana, Y., Sugiyama, N. (2010): Effects of tape covering and vine vigor on developement of surface callus in girdle of grapevine. Vitis 49 (3), 107-111.

[39.] Yamane, T., Shibayama, K. (2006). Effects of Trunk Girdling and Crop Load Levels on Fruit Quality and Root Elongation in 'Aki Queen' Grapevines. Journal of the Japanese Society for Horticultural Science, 75 (6), 439-444. https://doi.org/10.2503/jjshs.75.439

[40.] Zabadal, T. J. (1992). Response of 'Himrod' Grapevines to Cane Girdling. HortScience - American Society for Horticultural Science. 27 (9), 975-976. https://doi.org/10.21273/HORTSCI.27.9.975

[41.] Zanathy, G. (2003): A szőlőfürtök körüli levelek ritkítása. Növénytermesztés, 2003 (7). Digitalized: https:/www.agronaplo.hu/szakfolyoirat/2003/7/ novenytermesztes/a-szolofurtok-koruli-levelek-ritkitasa 
[42.] Zhang, X., Luo, G., Wang, R.,Wang, J., Himmelrick, D. G.(2003). Growth and developmental Responses of seeded and Seedless Grape Berries to Shoot Girdling. Journal of the American Society for Horticultural Science, 128 (3): 316323.

https://doi.org/10.21273/JASHS.128.3.0316

[43.] Zsófi, Zs. Tóth E., Váradi Gy., Rusjan D. and Bálo, B. (2008). The effect of progressive drought on water relations and photosynthetic performance of two grapevine cultivars (Vitis vinifera L.). Acta Biologica Szegediensis, 52(2), 321322. 